Izabela Marciniak

Uniwersytet im. Adama Mickiewicza, Poznań

\title{
ROLA REFLEKSJI W PROCESIE PRZYGOTOWANIA DO ZAWODU NAUCZYCIELA JĘZYKA OBCEGO
}

\author{
The role of reflection in the process of foreign language \\ teacher training
}

\begin{abstract}
The process of foreign language teacher training requires the introduction and development of reflection skills for teaching and work as an educator. That is why the process of teacher training must provide students with the necessary knowledge and practice. This article presents the rationale of the teacher training process at the Institute of German Philology, Adam Mickiewicz University in Poznań, according to the standards for teaching from the years 2004 and 2012. The research described concerns the role of self-reflection in students both during the process of their training as future teachers and in their teaching practice in schools.
\end{abstract}

Keywords: language teacher development, social competences, teachers' professionalism, teacher autonomy, students' reflections

Słowa kluczowe: kształcenie nauczycieli języków obcych, kompetencje społeczne, profesjonalizm w nauczaniu, autonomia nauczyciela, refleksje studentów

\section{Wstęp}

Zagadnienie refleksji w działaniu i nad działaniem cieszy się dużym zainteresowaniem przedstawicieli różnych grup zawodowych od lat osiemdziesiątych XX wieku i publikacji Donalda Schöna pt. The Reflective Practitioner (1983). Kształtowanie postawy refleksyjnego praktyka jest także jednym z celów kształcenia przyszłych nauczycieli języków obcych (JO), co stało się bezpośrednią inspiracją do prezentacji własnych doświadczeń i wyników podjętych badań. 
W tekście przedstawione zostaną słownikowe definicje terminu refleksja oraz aspekt refleksyjności w wybranych badaniach glottodydaktycznych w Polsce i na świecie. Rozważania teoretyczne będą stanowić podstawę prezentacji i analizy koncepcji programu specjalności nauczycielskiej w Instytucie Filologii Germańskiej (IFG) Uniwersytetu im. Adama Mickiewicza w odniesieniu do obowiązujących standardów przygotowania do zawodu nauczyciela. Jednym z celów omawianej koncepcji programowej jest kształtowanie refleksyjnej postawy przyszłych nauczycieli języka niemieckiego. Zbadaniu modelu nauczania, ukierunkowanego na refleksyjność, posłuży studium przypadku, przybliżające podejmowane działania i doświadczenia studentów, którzy ukończyli proces kształcenia pedagogicznego i zdobyli kwalifikacje do nauczania języka niemieckiego. Celem badań będzie ewaluacja koncepcji programowej w zakresie budowania postaw refleksyjnych oraz zachęcenie innych instytucji kształcących nauczycieli języków obcych i pozostałych przedmiotów szkolnych do przyjrzenia się przedmiotowemu zagadnieniu.

\section{Rozważania wokół pojęcia refleksji i procesu kształtowania postawy refleksyjnej nauczycieli języków obcych}

W celu podjęcia rozważań nad rolą refleksji w procesie kształcenia przyszłych nauczycieli JO warto przyjrzeć się słownikowym definicjom tego pojęcia. Stanisław Dubisz (2006: 906) rozumie refleksję jako „głębsze zastanowienie, zastanawianie się, rozmyślanie nad czymś, rozważanie połączone z analizowaniem czegoś, myśl, wypowiedź będącą wynikiem zastanowienia się, rozmyślania". Elżbieta Sobol postrzega refleksję podobnie, jako „głębsze zastanowienie się, rozmyślanie, rozważanie połączone z analizą, wyjaśnianiem, tłumaczeniem, przewidywaniem itp.; wynik zastanawiania się, rozmyślania, namysł" (Sobol, 2001: 836). Witold Doroszewski eksponuje dwa znaczenia pojęcia refleksji, tj. 1. „głębsze zastanowienie, zastanawianie się, rozmyślanie nad czymś, rozważanie połączone z analizą, namysł” oraz 2. „wypowiedź będącą wynikiem zastanowienia się, rozmyślania" (Doroszewski, 1996: 873). Jeszcze więcej znaczeń przypisuje pojęciu refleksji Jerzy Bralczyk. Refleksja to dla niego 1. „głębsze zastanowienie się nad czymś, wywołane silnym przeżyciem”, 2. „myśl lub wypowiedź będąca wynikiem takiego zastanowienia się”, 3. filoz. „zwrócenie się podmiotu myślącego ku własnej aktywności”, 4. filoz. „czynnik aktu świadomości stanowiący o tym, że spełniając go, uprzytamniamy sobie jego zachodzenie" (Bralczyk, 2005: 697). Odnosząc powyższe definicje do sytuacji pedagogiczno-dydaktycznych można więc przyjąć, że refleksja to zarówno proces 
głębszego zastanawiania się i analizowania, często zwrócony ku własnej aktywności, jak i myśl będąca wynikiem tego procesu.

Zdolność do refleksji jest cechą przypisywaną każdemu człowiekowi. Jej rozwój zależy od wielu czynników, w tym „od zadatków wrodzonych, procesu kształcenia i wychowania oraz od ukierunkowanej aktywności własnej człowieka" (Borkowski, 2003: 113). Wielki wpływ na poziom tej zdolności mają kompetencje społeczne (Borkowski, 2003: 107), potrzebne do pracy z ludźmi, bez których nie można sobie wyobrazić współczesnego nauczyciela.

W grupie kompetencji społecznych, które silnie determinują stopień rozwinięcia postawy refleksyjnej, znajdują się walory osobowościowe (m.in. dojrzałość emocjonalna i intelektualna, odpowiedzialność, ambicja, otwartość na zmiany, silna wola, zainteresowania), doświadczenie życiowe, inteligencja społeczna, autorytet oraz przede wszystkim wiedza. Jan Borkowski dostrzegając względny, przemijający i chwilowy charakter wiedzy i wykształcenia, zachęca do wyrabiania koniecznego nawyku systematycznego, niekończącego się doskonalenia. „Proces permanentnego kształcenia się (w sposób formalny i drogą nieustannego samokształcenia) nie tylko zapewnia nadążanie za tempem zmian cywilizacyjno-kulturowych oraz zawodowych, ale także, co ważniejsze, jest warunkiem kreatywnego wprowadzania innowacji i ich wyprzedzania" (Borkowski, 2003: 110-111).

Wspomniane przez Borkowskiego wprowadzanie innowacji jest jednym z elementów postawy refleksyjnego praktyka, opisywanej przez Donalda Schöna (1930-1997). Schön, dla którego inspiracją były prace Johna Deweya (1859-1952), koncentruje się na roli refleksji w dynamicznie zmieniających się sytuacjach pedagogicznych. Wychodząc z założenia, że nauczyciel nie ma nigdy do czynienia z identycznymi problemami i uwarunkowaniami sytuacyjnymi oraz że sytuacje dydaktyczne są niepowtarzalne, Schön twierdzi, że „podstawową umiejętnością nauczyciela powinno być radzenie sobie z niestabilnością, niepewnością i unikatowością działania pedagogicznego" (Zawadzka, 2004: 299) oraz dowodzi, że „wszyscy posiadamy zbiór własnych teorii dla różnych sytuacji życiowych i zawodowych. Teorie te budowane są na własnym doświadczeniu i wiedzy i działają najczęściej w ukryty sposób. Decydują one o naszym widzeniu danego problemu i wyborze sposobów poradzenia sobie z nim" (Filipowicz, 2005). Według Schöna oznaką profesjonalizmu wysokiej klasy jest „umiejętność świadomej refleksji nad własnymi teoriami i dostosowania ich do zmieniającej się rzeczywistości" (Filipowicz, 2005). Zdolność tworzenia wiedzy i nowych wartości poznawczych w sytuacjach pedagogicznych jest dla niego ważną cechą refleksyjnej praktyki (Zawadzka, 2004: 299). Refleksyjny praktyk to zatem nauczyciel, który korzysta z wiedzy opartej o naukowe badania, jednak jeśli nie dostrzega skuteczności 
podejmowanych działań, jest skłonny i zdolny do tworzenia własnych teorii i ich zweryfikowania. Cechuje go duża elastyczność w rozpoznaniu i analizie problemu, kreatywność i chęć stawienia czoła nowym sytuacjom. Refleksyjny praktyk łączy zatem umiejętnie teorię z praktyką (Filipowicz, 2005).

O związku teorii z praktyką w kształceniu nauczycieli pisze Allen T. Pearson (1994), który wychodzi od zdefiniowania czynności nauczania jako działania zamierzonego. Pearson podkreśla rolę wiedzy, będącej rezultatem badania, refleksji, eksperymentu i doświadczenia, która jest konieczna do uprawiania praktyki. Wśród różnych rodzajów wiedzy koniecznej, Pearson wymienia m.in. wiedzę opartą na doświadczeniu i widzi w niej odpowiednik refleksji w działaniu w ujęciu Schöna. Pearson zachęca wykładowców akademickich, aby nie mówili studentom, co mają wiedzieć, ale ułatwili im samodzielne dojście do wiedzy. Wśród zadań wykładowców wymienia obserwowanie studentów, dawanie wskazówek, sugerowanie alternatyw, zadawanie pytań, dawanie moralnego i psychicznego wsparcia i wzmacnianie motywacji (Pearson, 1994: 166-167).

Zagadnienie refleksji jest coraz powszechniejsze w prowadzonych obecnie badaniach glottodydaktycznych, przy czym jest ono albo głównym przedmiotem badania albo aspektem towarzyszącym badaniu innego zagadnienia. Koncentrując się na roli refleksji w życiu zawodowym nauczycieli JO i w procesie przygotowania do zawodu należy wspomnieć rozważania Hanny Komorowskiej (2001: 201), która widzi dwie najważniejsze przesłanki w rozwoju własnym nauczycieli: odwzorowanie cudzych, skutecznych zachowań pedagogicznych oraz „krytyczną refleksję nad naszym własnym zachowaniem w zestawieniu z postawionymi sobie celami i na tle reakcji uczniów na to, co robimy". Uznając ważność i wartość obu tych dróg, tę drugą nazywa gwarantem stałego rozwoju i doskonalenia oraz fundamentem autonomii nauczyciela.

Wśród badań glottodydaktycznych, które bezpośrednio lub pośrednio dotyczą postawy refleksyjnej nauczycieli języków obcych, warto wymienić badania Marii Wysockiej (2003), która zgłębia zagadnienie profesjonalizmu w nauczaniu JO. Dowodzi ona, że optymalnym modelem rozwoju kompetencji profesjonalnej nauczycieli jest refleksyjny model kształcenia. Zadanie konieczności przekazania metodycznej wiedzy wraz z krytycznym i refleksyjnym podejściem do niej oraz przekonaniem, że każdy nauczyciel musi być jednocześnie badaczem własnej praktyki, opisuje Marzena Żylińska (2002), inspirowana lekturą tekstu Pearsona (1994). Dorota Werbińska (2006), zajmująca się skutecznością nauczycieli JO i ich personalnymi teoriami, mocno odwołuje się do teorii refleksyjnej praktyki. Podkreśla tym samym, że każdy nauczyciel powinien poddawać ustawicznej refleksji własną praktykę zawodową i być gotowy zmieniać swoje przekonania. To samo odwołanie teoretyczne 
znajdujemy w badaniach Małgorzaty Piotrowskiej-Skrzypek (2008), która stawia tezę, że bycie refleksyjnym praktykiem może wpłynąć na refleksyjność uczniów i wywołać intencjonalność uczenia się.

Rok 2009 obfituje w publikacje, w których opisywany jest aspekt refleksji. Anna Michońska-Stadnik (2009) dowodzi, że autonomia nauczyciela jest konsekwencją jego refleksyjnej postawy. Małgorzata Adams-Tukiendorf (2009) zachęca do przeniesienia nurtu zwanego couchingiem do edukacji i wykorzystania jego potencjału $w$ trakcie wspierania procesu refleksji nauczycieli, między innymi przy zastosowaniu techniki STRIDE. Magdalena Witkowska (2009), próbując znaleźć odpowiedź na pytanie, dlaczego warto i jak można kształcić postawę refleksyjną studentów-kandydatów na nauczycieli języka angielskiego, nazywa refleksję kluczem do efektywnego uczenia się i nauczania. Weronika Wilczyńska (2009), zachęcając nauczycieli do podejmowania badań nad własnymi działaniami zawodowymi, podaje jako warunek konieczny nabranie refleksyjnego dystansu wobec własnej praktyki dydaktycznej. Edyta Wajda (2009), badająca samoocenę nauczycieli JO, postrzega ją jako element refleksyjnej praktyki nauczycielskiej.

Kolejne lata przynoszą dalsze doniesienia naukowe w obszarze refleksji. Joanna Stańczyk (2010), która prowadzone badanie w działaniu opiera na twierdzeniu, iż umiejętność obserwacji i poddawania refleksji własnych działań jest immanentną częścią procesu kształcenia się i podstawą transferu nabywanych umiejętności i wiedzy do dowolnej sytuacji zawodowej, bada dojrzewanie słuchaczy nauczycielskich kolegiów języków obcych do postawy refleksyjnej. Autorka definiuje refleksję jako wewnętrzny proces poznawczy i afektywny, „którego rezultat znajduje odzwierciedlenie w potencjalnej zmianie zachowań w działaniu" (Stańczyk, 2010: 161). Sebastian Chudak (2010) analizuje umiejętność polskich studentów przygotowujących się do nauczania języka niemieckiego do refleksji nad własną kulturą, przy czym widzi to działanie jako czynnik konieczny do budowania studenckiej kompetencji interkulturowej. O przykładach budowania postawy refleksyjnej studentów-praktykantów piszą Iwona Kretek i Regina Strzemeska (2010) i stwierdzają we wnioskach, że refleksja wymaga czasu, bodźców, wiedzy oraz sterowania w początkowej fazie. Chociaż kształtowanie postawy refleksyjnej wymaga sporo wysiłków i działań, autorki podkreślają, że tylko taka postawa studentów może zagwarantować ich rozwój w zawodzie nauczyciela.

Jedną z najnowszych publikacji, w której dużo uwagi poświęca się istocie refleksji i opisowi jej funkcji oraz miejsca we współczesnej glottodydaktyce, jest książka Anny Michońskiej-Stadnik (2013). Autorka analizuje teoretyczne i praktyczne postawy weryfikacji teorii subiektywnych w kształceniu nauczycieli JO i w tych teoriach widzi punkt wyjścia do refleksji. Zachęca też 
podmioty kształcące przyszłych nauczycieli do wykorzystania potencjału tkwiącego w Europejskim portfolio dla studentów-przyszłych nauczycieli języków w budowaniu postaw refleksyjnych.

Wymienione powyżej publikacje stanowią wybór tekstów specjalistycznych, poświęconych zagadnieniu refleksji i jednocześnie dają obraz stopnia intensywności prac. Pozwalają także przypuszczać, że zagadnienie będzie się cieszyć dużym zainteresowaniem badaczy i nauczycieli języków obcych w przyszłości. Przytoczone przykłady rozważań teoretycznych i badań zachęcają do zastanowienia się, jak można rozwijać zdolność refleksji w trakcie przygotowania studentów filologii do wykonywania zawodu nauczyciela JO.

\section{Rola refleksji studenckiej w procesie kształcenia nauczycieli języka niemieckiego w Instytucie Filologii Germańskiej UAM według standardów z roku 2004}

Koncepcje kształcenia nauczycieli bazują w Polsce na standardach ministerialnych. Każda instytucja prowadząca kształcenie przyszłych nauczycieli ma obowiązek skonstruowania programu kursu odpowiadającego powszechnie przyjętej koncepcji. Studenci, którzy rozpoczęli studia wyższe w roku 2011 lub wcześniej, realizowali standardy kształcenia nauczycieli z 2004 roku (Rozporządzenie Ministra Edukacji Narodowej i Sportu z dn. 7.09.2004, Dz.U. Nr 207 poz. 2110). Cechą charakterystyczną tego dokumentu był fakt różnicowania sposobu przygotowania przyszłych nauczycieli do zawodu w zależności od typu studiów. Specjalizacja nauczycielska na wyższych studiach zawodowych (tj. studiach trzyletnich) była prowadzona obligatoryjnie w zakresie dwóch specjalności (głównej i dodatkowej), zaś w ramach uzupełniających studiów magisterskich, jednolitych studiów magisterskich i studiów podyplomowych specjalność dodatkowa była fakultatywna. W przypadku ukończenia studiów licencjackich na kierunku filologia studenci mogli uzyskać kwalifikacje do nauczania we wszystkich typach szkół. Standardy z roku 2004 opisywały sylwetkę absolwenta specjalności nauczycielskiej, wskazywały przedmioty i ich wymiar godzinowy oraz określały ramy praktyki pedagogicznej. W kwestii rozwijania umiejętności refleksji standardy mówiły niewiele. Krótkie fragmenty znaleźć można w opisie sylwetki absolwenta, w treściach programowych psychologii i pedagogiki oraz $\mathrm{w}$ charakterystyce praktyki pedagogicznej:

II Sylwetka absolwenta, p. 3) dydaktyka przedmiotowa - student powinien umieć „badać i oceniać osiągnięcia uczniów oraz własną praktykę” (Rozporządzenie, 2004: 3 zał.)

VII Treści programowe przedmiotów 
B.1 Psychologia „Nauczyciel jako osoba ucząca się - ewaluacja własnej pracy i osiągnięć" (Rozporządzenie, 2004: 8 zał.)

B.2 Pedagogika „Badanie własnej praktyki oraz poddawanie jej krytyce przez własne publikacje. Tworzenie własnych koncepcji pedagogicznych na podstawie krytycznej refleksji nad aktualnym stanem wiedzy" (Rozporządzenie, 2004: 8 zał.)

$X$ Praktyki pedagogiczne

Celem praktyki jest „5) nabycie umiejętności analizowania własnej pracy i jej efektów oraz pracy uczniów" (Rozporządzenie, 2004: 10 zał.).

W związku z tak sformułowanymi celami w standardach, zadaniem nauczycieli akademickich było określenie, jak można tego dokonać. W IFG UAM przyjęto założenie, że zdolność do refleksji można i należy nieustannie rozwijać w różnych sytuacjach. Wypracowano zatem sposoby osiągnięcia tego celu, które na przestrzeni kilku lat obowiązywania dokumentu były ciągle doskonalone i uzupełniane. W trakcie zajęć teoretycznych wielokrotnie odwoływano się do doświadczeń edukacyjnych studentów w czasie omawiania treści psychologiczno-pedagogicznych i dydaktycznych. Każda nowa treść poprzedzona była rozmową ze studentami o ich wspomnieniach z czasów szkolnych, na przykład rozpoczynając omawianie pracy nad leksyką obcojęzyczną studenci wypowiadali własne odczucia na temat roli słownictwa w komunikacji, cech tego podsystemu językowego, opowiadali o swoich sposobach uczenia się słownictwa i o wsparciu ich wysiłków przez nauczycieli. Ta część zajęć poświęcona wspomnieniom zawsze bardzo aktywizowała studentów i zachęcała ich do porównań i refleksji. Kolejnym zadaniem skłaniającym studentów do zastanawiania się było opracowywanie konspektów lekcji połączone z wielokrotnym formułowaniem pytań: Dlaczego? Jakie inne formy można by zastosować? Jakie miałoby to skutki?

Regulamin praktyki pedagogicznej w IFG zapewniał studentom możliwość grupowych obserwacji lekcji z nauczycielem akademickim we wszystkich typach szkół, w których absolwenci specjalności mogli nauczać. Ta formuła, tak trudna organizacyjnie (pozyskiwanie szkół i nauczycieli gotowych do współpracy, dopasowanie planu zajęć studentów do możliwości szkół), przynosiła największe korzyści w rozwijaniu refleksyjnej postawy studentów. Każda obserwowana lekcja była omawiana z instytutowym mentorem pod kątem treści psychologicznych, pedagogicznych i dydaktycznych. Studenci mieli możliwość obserwowania m.in. różnorodnych osobowości dydaktycznych, sytuacji w klasie, trybu pracy szkoły, zastosowania mediów, używania języka ojczystego na lekcji JO, sposobów oceniania uczniów. Potem mogli wypowiadać swoje spostrzeżenia, snuć domysły, szukać uzasadnień dla poszczególnych działań i budować wizję własnego postępowania w czasie swojej praktyki w szkole. Etap 
grupowych obserwacji lekcji w szkole zawsze wiązał się z silnym wzrostem motywacji studentów-praktykantów. Czasem wzmożonej refleksji była też indywidualna praktyka pedagogiczna studentów w szkole pod opieką nauczyciela dyplomowanego lub mianowanego. Jeszcze w czasie zajęć teoretycznych zwracano uwagę studentów na rolę informacji zwrotnej po przeprowadzonych przez nich lekcjach, zachęcano ich do ewaluacji każdej lekcji z opiekunem, zobowiązano do napisania komentarza dydaktycznego po wszystkich lekcjach. Aby pogłębić refleksję łączącą teorię z praktyką, zaplanowano także grupową rozmowę ewaluacyjną z uczelnianym opiekunem studentów-praktykantów. Ta forma zawsze dostarczała nauczycielowi akademickiemu możliwość oceny wiedzy merytorycznej studentów, ich motywacji i dojrzałości do pracy w zawodzie nauczyciela oraz zdolności do refleksji. Uzupełnieniem ustnej ewaluacji była jeszcze praca pisemna pt. Moje refleksje po praktyce pedagogicznej. Aby przekonać się, jakie refleksje towarzyszyły studentom w trakcie przygotowania do wykonywania zawodu nauczyciela, przeprowadzono w IFG badanie, którego wyniki opisane zostaną w punkcie piątym.

\section{Kształtowanie postawy refleksyjnej studentów w Instytucie Filologii Germańskiej UAM według standardów z roku 2012}

Na początku 2012 roku wprowadzono nowe standardy kształcenia przygotowujące do wykonywania zawodu nauczyciela (Rozporządzenie MNiSW z dn. 17.01.2012, Dz. U. poz. 131). Studenci, którzy rozpoczęli studia od 2012 roku i wybrali specjalność nauczycielską, są zobowiązani do osiągnięcia określonych efektów kształcenia w ramach obowiązkowych modułów specjalności nauczycielskiej. Moduł pierwszy obejmuje przygotowanie merytoryczne do nauczania danego przedmiotu, drugi przedmioty psychologiczno-pedagogiczne, trzeci dydaktykę danego przedmiotu. Instytucje prowadzące kształcenie nauczycieli mają też możliwość zaproponować studentom moduł czwarty, przygotowujący do nauczania kolejnego przedmiotu oraz moduł piąty, w zakresie pedagogiki specjalnej. Dwa ostatnie moduły mają charakter fakultatywny.

Standardy z roku 2012 przewidują minimalne ilości godzin na poszczególne elementy modułów. Moduł drugi, psychologiczno-pedagogiczny, obejmuje minimum 180 godzin (90 godzin ogólnego przygotowania psychologiczno-pedagogicznego, 60 godzin przygotowania na danym etapie edukacyjnym oraz 30 godzin praktyki), zaś trzeci, dydaktyczny, minimum 240 godzin (30 godzin podstaw dydaktyki, 90 godzin dydaktyki przedmiotu na danym etapie edukacyjnym oraz 120 godzin praktyki). Standardy te zmieniają zakres kwalifikacji absolwentów specjalności nauczycielskiej w porównaniu z poprzednim 
modelem. Na studiach I stopnia studenci filologii mogą zdobyć uprawnienia do nauczania języka obcego na II etapie edukacyjnym, a więc w klasach IV-VI szkoły podstawowej, a dopiero na studiach II stopnia uprawnienia do nauczania na wszystkich etapach edukacyjnych.

Autorzy nowych standardów poświęcają nieco więcej uwagi roli refleksji w przygotowaniu do wykonywania zawodu nauczyciela. W opisie ogólnych efektów kształcenia czytamy: „Po zakończeniu kształcenia przygotowującego do wykonywania zawodu nauczyciela absolwent: (...) 6) charakteryzuje się wrażliwością etyczną, empatią, otwartością, refleksyjnością oraz postawami prospołecznymi i poczuciem odpowiedzialności" (Rozporządzenie, 2012: 1 zał.). W opisie szczegółowych efektów kształcenia napisano, że absolwent „3) w zakresie kompetencji społecznych: d) ma świadomość znaczenia profesjonalizmu, refleksji na tematy etyczne i przestrzegania zasad etyki zawodowej; wykazuje cechy refleksyjnego praktyka" (Rozporządzenie, 2012: 3 zał.). Opis praktyki pedagogicznej silnie eksponuje rolę refleksji w różnych działaniach:

W trakcie praktyki następuje kształtowanie kompetencji dydaktycznych przez:

5) analizę i interpretację zaobserwowanych albo doświadczanych sytuacji i zdarzeń pedagogicznych, w tym:
a) prowadzenie dokumentacji praktyki,
b) konfrontowanie wiedzy teoretycznej z praktyką,
c) ocenę własnego funkcjonowania w toku wypełniania roli nauczyciela (dostrzeganie swoich mocnych i słabych stron),
d) ocenę przebiegu prowadzonych lekcji (zajęć) oraz realizacji zamie- rzonych celów,
e) konsultacje z opiekunem praktyk w celu omawiania obserwowanych i prowadzonych lekcji (zajęć),
f) omawianie zgromadzonych doświadczeń w grupie studentów (słu- chaczy)" (Rozporządzenie, 2012: 20-21 zał.).

Wymienione wyżej cele są realizowane w IFG UAM w różnorodny sposób. Staramy się wykorzystywać wieloletnie doświadczenia oraz sprawdzone wzorce i na bieżąco modyfikujemy nasze działania. Dajemy studentom przykład własną refleksyjną postawą i uczymy ich stawania się refleksyjnym praktykiem. Spośród sprawdzonych sposobów kształtowania refleksyjnej postawy studenta-praktykanta, opisanych w punkcie trzecim, nadal zakładamy częste odwołania do doświadczeń edukacyjnych studentów, utrzymujemy, mimo trudności organizacyjnych, obserwacje grupowe z nauczycielem akademickim w szkołach i ich omówienia, zachowujemy formę ewaluacji praktyki w szkole i na uczelni. Aby uświadomić studentom rolę refleksji, sformułowaliśmy w opisie przedmiotów, sporządzonym zgodnie z zaleceniami Krajowych 
Ram Kwalifikacji, określone efekty kształcenia i założyliśmy metody ich osiągania. Dla przykładu w opisie praktyki pedagogicznej student zapozna się z obowiązującymi go efektami kształcenia, między innymi:

- EK: PRPED-DL2II_08: student współdziała z opiekunem w zakresie oceniania prac uczniów - metoda oceniania: raport podsumowujący błędy popełnione przez uczniów;

- EK: PRPED-DL2II_11: student uwzględnia specjalne potrzeby edukacyjne uczniów - metoda oceniania: studium przypadku

- EK: PRPED-DL2II_14: dokonuje oceny własnego funkcjonowania w toku wypełniania roli nauczyciela - metoda oceniania: notowanie bieżących refleksji w dzienniczku praktyk.

Wszystkie założone efekty kształcenia wynikają z dostosowania koncepcji programu specjalności nauczycielskiej w IFG do wymagań standardów kształcenia nauczycieli z roku 2012.

\section{Badanie refleksyjnej postawy absolwentów specjalności nauczycielskiej w IFG UAM}

Budowanie refleksyjnej postawy przyszłych nauczycieli języka niemieckiego jest ważnym celem programu specjalności nauczycielskiej w IFG UAM i jednocześnie przedmiotem opisywanego studium przypadku. Koncepcja programowa, działania nauczycieli akademickich i częściowa ewaluacja, oparta na obserwacji studentów i rozmowach z nimi, zostały przedstawione w punkcie trzecim. Punkt piąty poświęcony jest dalszej ewaluacji koncepcji programowej, a szczególnie prezentacji refleksji, które towarzyszyły studentom w czasie teoretycznego i praktycznego przygotowania do wykonywania zawodu. Dane pozyskane dzięki przeprowadzonej ankiecie służą jakościowej interpretacji działań podejmowanych na uczelni.

W kwietniu i maju 2013 roku zostało przeprowadzone w IFG UAM badanie ankietowe. Do wzięcia udziału w badaniu zaproszono 60 studentów filologii germańskiej, którzy w ostatnich trzech latach zdobyli kwalifikacje do nauczania języka niemieckiego według standardów 2004. Na zaproszenie odpowiedziały 32 osoby: 9 osób z III roku studiów licencjackich (tryb stacjonarny), 6 osób z I roku i 5 osób z II roku studiów drugiego stopnia (tryb stacjonarny) oraz 12 studentów II roku studiów drugiego stopnia (tryb niestacjonarny). Dwadzieścia osób zdobyto kwalifikacje na uniwersytecie, jedna osoba w wyższej szkole zawodowej oraz jedenaście w nauczycielskich kolegiach języków obcych.

Studentom postawiono dwa pytania o charakterze otwartym. Ta formuła pytań była w pełni zamierzona. Wprawdzie utrudnia $z$ jednej strony 
systematyczne podliczenie danych z powodu nieograniczonej różnorodności sformułowań, z drugiej zaś jednak daje respondentom pełną swobodę wypowiedzi i nic nie sugeruje.

W odpowiedzi na pierwsze pytanie o refleksje towarzyszące studentom w trakcie teoretycznego przygotowania do wykonywania zawodu nauczyciela języka niemieckiego respondenci zapisali następujące sformułowania:

- czy wiedza teoretyczna znajdzie zastosowanie w praktyce? (7)

- ważna jest nie tylko wiedza teoretyczna, ale także umiejętności jej przekazywania (4)

- dydaktyka jest bardzo obszerną dyscypliną (4)

- treści teoretyczne tworzą bazę do pracy w szkole (4)

- $\quad$ w teorii wszystko wydaje się proste i nieskomplikowane (1)

- nauczyciel odgrywa ważną rolę w procesie dydaktycznym (4)

- czy nadaję się na nauczyciela? (4)

- jakie predyspozycje konieczne są do wykonywania zawodu nauczyciela? (3)

- czy uda mi się wzbudzić zainteresowanie uczniów? (1)

- czy będę w stanie wypracować sobie szacunek u uczniów? (1)

- nauczyciel to zawód trudny, wymagający zaangażowania (1)

- wcześniej, będąc uczniem, nie zauważałem ogromnego wkładu pracy moich nauczycieli (1)

Dużo miejsca zajmowała refleksja na temat roli refleksji w zawodzie nauczyciela. Refleksyjność nauczycieli jest konieczna, by mogli oni wciąż na nowo oceniać i optymalizować swoje działania.

Dużo więcej refleksji studenci zapisali w odpowiedzi na drugie pytanie, które dotyczyło ich refleksji w czasie odbywanej praktyki pedagogicznej. Były to następujące przemyślenia:

- czy przeprowadziłam lekcję poprawnie, zgodnie z planem? co było pozytywne, co można zrobić inaczej? (7)

- jak ważna jest u nauczyciela umiejętność motywowania uczniów (6)

- praca w szkole może naprawdę sprawiać przyjemność (5)

- praktyka w szkole zupełnie różni się od teorii omawianej na zajęciach (4)

- ważna jest osobowość nauczyciela (cierpliwość, zaangażowanie, opanowanie) (4)

- praktyka pokazała, jak odpowiedzialnym zadaniem jest praca nauczyciela (3)

- każdego ucznia należy traktować indywidualnie (4)

- dużo czasu potrzeba na przygotowanie lekcji (3)

- ważna jest elastyczność, a nie sztywne trzymanie się konspektu (3)

- nauczyciel musi być kompetentny (3)

- nauczyciel powinien ciągle się doskonalić (2)

- byłam pozytywnie zaskoczona każdym dniem (2)

- bardzo ważne jest chwalenie uczniów (1) 
- ważne jest aktywizowanie wszystkich uczniów (1)

- nauczyciel powinien dostosować techniki dydaktyczne do potrzeb uczniów z dysleksją (1)

- nauczyciel powinien umieć uczniów słuchać (1)

- należy znaleźć z uczniem wspólny język (1)

- $\quad$ spostrzeżenia i reakcje uczniów w czasie lekcji mogą być bardzo różne (1)

- każdy uczeń wnosi coś w lekcję (1)

- $\quad$ kontakt z uczniami weryfikuje posiadaną wiedzę i umiejętności (1)

- $\quad$ trzeba poznać każdą grupę uczniów (1)

- jak można utrzymać miłą atmosferę w klasie? (1)

- $\quad$ z każdą przeprowadzoną lekcją wzrastały moje kompetencje (1)

- aktywność zawodowa zwiększa częstotliwość refleksji (1)

- nauczanie kogoś musi być przemyślane (1)

- do każdej lekcji trzeba się przygotować (1)

- uświadomiłam sobie, że nabyta wiedza teoretyczna w pełni sprawdza się w praktyce (1)

- rola relacji uczeń - nauczyciel (1)

- nauczyciel w roli wychowawcy (1)

- $\quad$ na ile przydatna jest wiedza teoretyczna w praktyce? (1)

- jakie jest moje nastawienie do zawodu nauczyciela? (1)

- zawód nauczyciela to mój wymarzony zawód (1)

- $\quad$ kierując się jedynie książkowymi uogólnieniami nie można zostać dobrym nauczycielem (1)

- zajęcia teoretyczne nie są w stanie w pełni przygotować do prowadzenia zajęć (1)

- trudne jest reagowanie na złe zachowania uczniów (1)

- jak powinien reagować nauczyciel w sytuacjach trudnych? (1)

- nie jestem jeszcze gotowa do pracy w zawodzie nauczyciela (1).

Przyrost refleksji, ich różnorodność i wieloaspektowość pokazują, że potencjał studentów wzrasta w miarę upływu czasu i nabywania doświadczeń w praktyce. Na podstawie wszystkich działań ewaluacyjnych można stwierdzić, że koncepcja programowa w IFG UAM, nastawiona na budowanie refleksyjnej postawy studentów, spełnia swoje zadania. W czasie rozmów ze studentami, grupowych obserwacji lekcji w szkołach, hospitacji lekcji studentów przebywających na praktyce i rozmów pohospitacyjnych widać stopniowe dojrzewanie studentów do refleksji, popartej solidną wiedzą teoretyczną. Badania ankietowe dają obraz konkretnych przemyśleń studentów. W tych różnorodnych przemyśleniach odzwierciedlają się wysiłki nauczycieli akademickich, podejmowane w czasie trwania tego procesu. Można zauważyć, że niektóre zamierzenia wykładowców zachęciły studentów do refleksji dopiero w czasie konfrontacji teorii z praktyką. W związku z powyższym trzeba doło- 
żyć wszelkich starań, aby praktyka pedagogiczna była działaniem w pełni zaplanowanym i przemyślanym. Warto zadbać o to, aby uczelnie i placówki oświatowe współdziałały w tworzeniu koncepcji odbywania praktyki pedagogicznej przez studentów. Każda uczelnia powinna korzystać ze swojego prawa określenia kształtu praktyki i wyposażyć studenta-praktykanta w regulamin praktyki oraz zestaw zadań do wykonania. Warto również skierować prośbę do szkolnych opiekunów studentów-praktykantów o ewaluację uczelnianej koncepcji kształcenia i informację zwrotną. Konfrontacja teorii i praktyki kształcenia przyszłych nauczycieli może przynieść korzyści wszystkim podmiotom tego procesu.

Analiza pozyskanych danych daje podstawę do sformułowania wniosku, że studenci, którzy zdobyli już kwalifikacje do nauczania, osiągnęli względnie wysoki poziom refleksyjności i można mieć nadzieję, że mają szansę nadal pogłębiać tę zdolność i rozwijać profesjonalizm. Są bez wątpienia świadomi problemów i trudności, ale także przygotowani do ich rozwiązywania i modyfikowania własnych działań.

\section{Podsumowanie}

Czas przygotowania do zawodu nauczyciela JO jest bardzo krótki. W tym okresie student musi zgłębić obszerną wiedzę specjalistyczną, psychologicznopedagogiczną i dydaktyczną, skonfrontować teorię z praktyką oraz wykształcić określone umiejętności. Z uwagi na to, że czas realizacji programu specjalności nauczycielskiej znacznie ogranicza stopień osiągnięcia tych celów, należy ten czas efektywnie wykorzystać. W zakresie wiedzy merytorycznej należy dokonać selekcji i gradacji najpotrzebniejszego materiału, zachęcić studentów do poszukiwania wiedzy w aktualnej literaturze specjalistycznej, nauczyć ich krytycznie korzystać ze źródeł oraz przede wszystkim przygotować do ustawicznego doskonalenia się w ramach rozwijania wszystkich kompetencji nauczycielskich. W odniesieniu do praktycznej strony zawodu nauczyciela studenci muszą mieć świadomość unikatowości i niepowtarzalności sytuacji pedagogicznych. Dlatego konieczne jest wykształcenie w nich gotowości do refleksji i wprowadzania innowacji. Tylko postawa refleksyjnego praktyka w połączeniu z profesjonalizmem jest w stanie zapewnić w zawodzie nauczyciela poczucie sukcesu zawodowego. Na zakończenie wyrażamy nadzieję, że poddana ewaluacji koncepcja kształcenia przyszłych nauczycieli języków obcych będzie głosem w dyskusji nad przygotowaniem filologów do pracy w oświacie i inspiracją do dalszych badań w kierunku rozwijania postaw refleksyjnych w zawodzie nauczyciela. 


\section{BIBLIOGRAFIA}

Adams-Tukiendorf, M. 2009. „Technika STRIDE jako narzędzie wspierające refleksyjność nauczycieli" (w:) Nauczyciele języków obcych dziś i jutro (red. M. Pawlak, A. Mystkowska-Wiertelak i A. Pietrzykowska). Poznań-Kalisz: Wydawnictwo UAM: 117-127.

Borkowski, J. 2003. Podstawy psychologii społecznej. Warszawa: Dom Wydawniczy ELIPSA.

Bralczyk, J. (red.) 2005. Słownik 100 tysięcy potrzebnych słów. Warszawa: PWN.

Chudak, S. 2010. „Über den Mythos polnischen Brotes ... Reflexion über den eigenkulturellen Hintergrund bei angehenden polnischen DaF-Lehrern als Beitrag zur Förderung ihrer interkulturellen kommunikativen Kompetenz. Überlegungen zum vorläufigen Ergebnis eines Seminars" (w:) Reflexion als Schlüsselphänomen der gegenwärtigen Fremdsprachendidaktik. (red. K. Myczko). Frankfurt am Main: Peter Lang: 225-236.

Doroszewski, W. (red.) 1996. Słownik języka polskiego, tom VIII. Warszawa: PWN Dubisz, S. (red.) 2006. Uniwersalny słownik języka polskiego, tom P-Ś. Warszawa: PWN. Filipowicz, G. 2005. „Refleksyjny praktyk“. http://kadry.nf.pl DW 3.05.2012.

Kretek, I. i R. Strzemeska. 2010. „Kollegstudenten als reflexive Praktikanten - Bedeutung der Reflexion während des Schulpraktikums" (w:) Reflexion als Schlüsselphänomen der gegenwärtigen Fremdsprachendidaktik (red. K. Myczko). Frankfurt am Main: Peter Lang: 237-247.

Komorowska, H. 2001. Metodyka nauczania języków obcych. Warszawa: Fraszka Edukacyjna.

Michońska-Stadnik, A. 2009. „Od wyboru podręcznika do rozwoju autonomicznego poznania. Rola refleksji w kształceniu nauczycieli języków obcych” (w:) Nauczyciele języków obcych dziś i jutro (red. M. Pawlak, A. MystkowskaWiertelak i A. Pietrzykowska). Poznań-Kalisz: Wydawnictwo UAM: 97-106.

Michońska-Stadnik, A. 2013. Teoretyczne i praktyczne podstawy weryfikacji wybranych teorii subiektywnych w kształceniu nauczycieli języków obcych. Wrocław: Wydawnictwo Uniwersytetu Wrocławskiego.

Pearson, A. T. 1994. Nauczyciel. Teoria i praktyka w kształceniu nauczycieli. Warszawa: Wydawnictwa Szkolne i Pedagogiczne.

Piotrowska-Skrzypek, M. 2008. „Uczę (się) refleksyjnie, więc jestem... autonomiczny? podejście refleksyjne na lekcjach języka obcego w gimnazjum" (w:) Autonomia w nauce języka obcego - co osiggnnęliśmy i dokq̨d zmierzamy (red. M. Pawlak). Poznań-Kalisz-Konin: Wydawnictwo UAM: 245-255.

Schön, D. 1983. The Reflective Practitioner: How Professionals Think in Action. New York: Basic Books.

Sobol, E. (red.) 2001. Podręczny słownik języka polskiego. Warszawa: PWN.

Stańczyk, J. 2010. „Poprzez refleksję do postawy refleksyjnej przyszłego nauczyciela języka obcego - trudności interpretacyjne badania w działaniu”. Neofilolog 34: 159-167.

Wajda, E. 2009. „Samoocena nauczyciela języków obcych” (w:) Skuteczna nauka języka obcego. Struktura i przebieg zajęć językowych (red. H. Komorowska). Warszawa: CODN: 71-80.

Werbińska, D. 2006. Skuteczny nauczyciel języka obcego. Warszawa: Fraszka Edukacyjna. 
Wilczyńska, W. 2009. „Nauczyciel języka obcego jako badacz (w:) Nauczyciele języków obcych dziś i jutro (red. M. Pawlak, A. Mystkowska-Wiertelak i A. Pietrzykowska). Poznań-Kalisz: Wydawnictwo UAM: 493-508.

Witkowska, M. 2009. „Refleksyjny student - refleksyjny praktyk. Kształcenie myślenia refleksyjnego przyszłych nauczycieli języka angielskiego" (w:) Nauczyciele języków obcych dziś i jutro (red. M. Pawlak, A. Mystkowska-Wiertelak i A. Pietrzykowska). Poznań-Kalisz: Wydawnictwo UAM: 129-140.

Wysocka, M. 2003. Profesjonalizm w nauczaniu języków obcych. Katowice: Wydawnictwo Uniwersytetu Śląskiego.

Zawadzka, E. 2004. Nauczyciele języków obcych w dobie przemian. Kraków: Impuls.

Żylińska, M. 2002. „Jak kształcić nauczycieli języków obcych”. Języki Obce w Szkole 5: 44-50. 